\title{
A BENCHMARKING METHODOLOGY FOR METALCASTING INDUSTRY
}

\author{
Laura M M Ribeiro*, GMM/IMAT, Dept. Eng. Metalúrgica e Materiais, Fac. de Engenharia da UP, Portugal - Iribeiro@fe.up.pt \\ J. A. Sarsfield Cabral, Dep. Eng. Mecânica e Gestão Industrial, Fac. de Engenharia da UP, Portugal - jacabral@fe.up.pt
}

Abstract: From the conceptual point of view, benchmarking seems a simple process. However, in practice a number of different models and approaches are used for assessing the companies' performance. In the first part of this paper some benchmarking methodologies used for the performance assessment are briefly analysed. In the following section, the planning stage of a specific benchmarking methodology for the foundry industry is presented. This methodology was developed within the scope of the ANALYSIS AND SELECTION OF BENCHMARKING METHODOLOGIES FOR METALCASTING INDUSTRY project. This project, which deserved the support of the Portuguese Foundry Association, was structured in two stages: (1) developing the model for the performance assessment (including performance indicators specially designed for the foundry companies), and (2) conducting a pilot benchmarking study in order to validate the model. Both stage (1) and stage (2) received the contribution of 8 relevant national foundries.

Keywords: benchmarking | performance indicators | manufacturing.

\section{BENCHMARKING METHODOLOGIES}

Benchmarking approaches vary both in the way the performance assessment models are conceived, and how in practice the methodology is used. Regarding the first aspect, there is an evident trend in developing the model according to the specific characteristics and needs of the benchmarking partners. Referring the methodology, a larger consensus seems to prevail: benchmarking is widely described as a structured process following sequential steps inspired in the Deming continuous improvement cycle: Plan (Plan), Collect (Do), Analyse (Check) and Adapt (Act).

Table 1 shows the activities that, according to seven different methodologies, have to be accomplished in each stage of a benchmarking exercise. These methodologies were selected because they are widely accepted and frequently mentioned in the literature. The differences are more obvious between those that were designed to assist a particular organisation (Alcoa, AT\&T) and those that were not developed under a specific organisation perspective (Camp, Spendolini, Karlöf, Codling, and Andersen). In spite of the differences, it can be concluded that all methodologies entail a sequence of steps that can be applied in broad contexts.

It is interesting to verify that all the methodologies recognise the importance of achieving depth understanding of the internal processes before exchanging data among benchmarking partners. They also emphasise the need of completing the exercise through the integration of the benchmarking findings (in order to improve the performance level).
However, some benchmarking methodologies differ in particular aspects. That is the case of the Alcoa's methodology. In fact, it does not point out the importance of the regular replication of the benchmarking process as a support for targeting performance indicators [1]. Additionally, some methodologies emphasise the planning stage (see for instance, AT\&T and Spendolini), pointing out the need of: (a) to assess the users expectations about benchmarking information, (b) to identify potentials barriers for the effective data exchange, (c) to create a learning environment, and (d) to obtain top management commitment and resources.

In brief, any of the methodologies referred in table 1 can be applied for helping the identification of strong and weak points. These methodologies (and many others quoted in the bibliography) also express the simplicity of benchmarking when regarded from the conceptual point of view. However, a common pitfall is to underestimate the amount of internal work required by this management tool. In fact, several benchmarking exercises did not succeed because the concerned organisations were not prepared (lack of commitment or insufficient resources) to endure a time consuming exercise, very demanding in terms of data gathering.

\section{A BENCHMARKING METHODOLOGY}

Benchmarking studies are usually lead by a certain organisation or a group of organisations. Independent entities (trade associations, technological centres, universities, etc...) have also promoted benchmarking activities as a key tool for improving their organisations performance. It is obvious that benchmarking approach largely depends on the type of the sponsor. 


\begin{tabular}{|c|c|c|c|c|}
\hline$>$ & PLAN $>$ & COLLECT & ANALYSE $>$ & ADAPX \\
\hline $\begin{array}{l}\text { Camp } \\
\text { 10-steps } \\
{[2]}\end{array}$ & $\begin{array}{l}\text { Planning } \\
\text { - Identify what is to be } \\
\text { benchmarked } \\
\text { - Identify comparative } \\
\text { companies } \\
\text { - Establish the methods for } \\
\text { collecting data }\end{array}$ & & $\begin{array}{l}\text { Analysis } \\
\text { - Determine current } \\
\text { performance gap } \\
\text { - Project future } \\
\text { performance levels }\end{array}$ & $\begin{array}{l}\text { Integration } \\
\text { - Communicate benchmark } \\
\text { findings and gain } \\
\text { acceptance } \\
\text { - Establish functional goals } \\
\text { Action } \\
\text { - Develop action plans } \\
\text { - Implement specific actions } \\
\text { and monitor progress } \\
\text { - Recalibrate benchmarks }\end{array}$ \\
\hline $\begin{array}{l}\text { Alcoa's } \\
\text { 6-steps } \\
{[3]}\end{array}$ & $\begin{array}{l}\text { - Decide what to benchmark } \\
\text { - check relevancy and } \\
\text { validity } \\
\text { - Planning the project } \\
\text { - select the team } \\
\text { - identify the customers } \\
\text { - establish the scope } \\
\text { - select the characteristics to } \\
\text { be measured } \\
\text { - identify information sources }\end{array}$ & $\begin{array}{l}\text { - Understanding your own } \\
\text { performance } \\
\text { - Studying others } \\
\text { - identify benchmarking } \\
\text { candidates } \\
\text { - prepare general and specific } \\
\text { questions } \\
\text { - prepare guidelines regarding } \\
\text { ethical and legal issues } \\
\text { - perform the study }\end{array}$ & $\begin{array}{l}\text { - Learning from the data } \\
\text { - analyse the data } \\
\text { - quantify the performance } \\
\text { gap }\end{array}$ & - Using the findings \\
\hline $\begin{array}{l}\text { AT\&T's } \\
\text { 12-steps } \\
{[3]}\end{array}$ & $\begin{array}{l}\text { - Determine who the clients } \\
\text { are } \\
\text { - Train the clients about } \\
\text { benchmarking } \\
\text { - Assess the clients } \\
\text { expectation } \\
\text { - Determine urgency } \\
\text { - Determine scope and type } \\
\text { of benchmarking needed } \\
\text { - Select and prepare the } \\
\text { team } \\
\text { - Obtain upper management } \\
\text { commitment }\end{array}$ & $\begin{array}{l}\text { - Develop the benchmarking } \\
\text { plan: } \\
\text { - prepare the mission } \\
\text { statement } \\
\text { - select collection method } \\
\text { - develop a profile for } \\
\text { selecting partners } \\
\text { - do research about potential } \\
\text { partners } \\
\text { - document the processes } \\
\text { - define metrics } \\
\text { - set up visits and protocol } \\
\text { - make visits and collect data }\end{array}$ & - Analyse the data & $\begin{array}{l}\text { - Integrate the } \\
\text { recommended actions } \\
\text { - Take action } \\
\text { - Continue improvement }\end{array}$ \\
\hline $\begin{array}{l}\text { Spendoli } \\
\text { ni } \\
\text { 5-steps } \\
{[4]}\end{array}$ & $\begin{array}{l}\text { - Identify what to benchmark } \\
\text { - identify customers } \\
\text { - identify the information } \\
\text { requirements } \\
\text { - define the specific subjects } \\
\text { to be benchmarked } \\
\text { - identify the resources } \\
\text { required }\end{array}$ & $\begin{array}{l}\text { - Form the benchmarking team } \\
\text { - define specific roles and team } \\
\text { members responsibilities } \\
\text { - train the team members in } \\
\text { project management tools } \\
\text { - Identify benchmarking } \\
\text { partners } \\
\text { - identify information sources }\end{array}$ & $\begin{array}{l}\text { - Collect and analyse } \\
\text { information } \\
\text { - select the collection } \\
\text { methods } \\
\text { - contact partners for } \\
\text { approval the bench. } \\
\text { code of conduct } \\
\text { - analyse information } \\
\text { - provide } \\
\text { recommendations for } \\
\text { action }\end{array}$ & $\begin{array}{l}\text { - Take action } \\
\text { - produce a report } \\
\text { - make improvement } \\
\text { recommendations } \\
\text { - follow-up the results } \\
\text { - continue the } \\
\text { benchmarking process }\end{array}$ \\
\hline $\begin{array}{l}\text { Karlöf, } \\
\text { Östblom } \\
\text { 5-stages } \\
{[5]}\end{array}$ & $\begin{array}{l}\text { Decide what to } \\
\text { benchmark } \\
\text { - identify the client's } \\
\text { information requirements } \\
\text { - identify the critical factors } \\
\text { Identify the benchmarking } \\
\text { partners }\end{array}$ & $\begin{array}{l}\text { Gather information } \\
\text { - document the processes } \\
\text { - collect data }\end{array}$ & $\begin{array}{l}\text { Analyse } \\
\text { - identify performance } \\
\text { gaps }\end{array}$ & $\begin{array}{l}\text { Implement for effect } \\
\text { - put improvements into } \\
\text { practice } \\
\text { - set realistic goals }\end{array}$ \\
\hline $\begin{array}{l}\text { Codling } \\
\text { 3-stages } \\
\text { 12-steps } \\
{[6]}\end{array}$ & $\begin{array}{l}\text { The planning stage } \\
\text { - select the subject area } \\
\text { - define the process } \\
\text { - identify potential partners } \\
\text { - identify data sources and } \\
\text { select appropriate } \\
\text { collection method }\end{array}$ & & $\begin{array}{l}\text { The analysis stage } \\
\text { - collect data and select } \\
\text { partners } \\
\text { - determine the gaps } \\
\text { - establish differences } \\
\text { - target future } \\
\text { performance }\end{array}$ & $\begin{array}{l}\text { The action stage } \\
\text { - communicate to } \\
\text { management \& others } \\
\text { - adjust goals and develop } \\
\text { improvement plan } \\
\text { - implement } \\
\text { - review progress and } \\
\text { calibrate }\end{array}$ \\
\hline $\begin{array}{l}\text { Andersen } \\
5 \text {-stages } \\
8 \text { steps } \\
{[7]}\end{array}$ & $\begin{array}{l}\text { Plan } \\
\text { - Determine the process to } \\
\text { benchmark } \\
\text { - Understand and document } \\
\text { own process } \\
\text { - Measure performance } \\
\text { own process }\end{array}$ & $\begin{array}{l}\text { Find } \\
\text { - Identify benchmarking } \\
\text { partners } \\
\text { Collect } \\
\text { - Understand and document } \\
\text { the partners' performance } \\
\text { and practice }\end{array}$ & $\begin{array}{l}\text { Analyse } \\
\text { - Identify gaps in } \\
\text { performance and the } \\
\text { root causes for the gaps }\end{array}$ & $\begin{array}{l}\text { Improve } \\
\text { - Plan the implementation } \\
\text { of improvements } \\
\text { - Implement improvements } \\
\text { and monitor the } \\
\text { implementation progress }\end{array}$ \\
\hline
\end{tabular}

Table 1 - Benchmarking methodologies 
However, in order to be successful, the methodology adopted (or designed) must be focused on the benchmarking partners needs and expectations.

The benchmarking methodology discussed in this paper was developed within the scope of the project Analysis and Selection of Benchmarking Methodologies for Metalcasting Industry. This project, which deserved the support of the Portuguese Foundry Association (APF), was structured in two stages: (1) developing the assessment performance model (including performance indicators specially designed for the foundry companies), and (2) conducting a pilot benchmarking study in order to validate the assessment performance model. The methodology followed the stages of the P-D-C-A cycle. The Planning stage (the only one that will be described in this paper) entailed the following sequenced steps:

1. Definition of the adhesion conditions;

2. Definition of the rules for the utilisation of the benchmarking results;

3. Selection of the benchmarking partners;

4. Promotion of upper management commitment;

5. Identification of the in-house benchmarking leader;

6. Collection and clarification of the expectations of the benchmarking partners;

7. Design of the performance assessment model:

- Identification of the key processes;

- Identification of the critical factors;

- Developing specific indicators for the processes evaluation;

8. Preparation the questionnaire and instructions for the data collecting;

9. Conduct a pilot benchmarking exercise to validate the assessment performance model.

During this stage, a group of 22 pre-selected foundries were contacted by telephone and by electronic mail. Visits were also carried out for (a) getting acquainted with the in-house benchmarking leader, (b) discussing the project in more detail, and (c) evaluating the expectations using a formal survey. This process was timeconsuming and slow: it was necessary a whole year to gain the acceptance of 8 foundries (out of the initial 22) for embarking in the development and validation of the benchmarking methodology (steps 3, 4, and 5).

All the in-house benchmarking leaders were at the senior manager level or executive director level. This was considered an important prerequisite for the participation in the assessment of the model design, assuring a global vision of the company.

An expectation survey was used at step 6 . The purpose of this survey was to evaluate the primary expectations of the partners group. This survey revealed the following priorities:

(a) to grasp and to disseminate internally the benchmarking methodology know-how;

(b) to acquire a foundry-oriented assessment model;

(c) to identify partners willing to share indicators and practices;

(d) to get a deep knowledge on the way the work is done;

(e) to identify weak and strong points and improvement opportunities, and

(f) to identify and adapt good practices of other companies.

Based on the experience obtained in previous empirical studies, it was decided that the assessment performance model should be based on 3 basic principles:

1. to be designed for and with the benchmarking partners, in order to create a model suitable for the specific characteristics of the steel and iron sandcasters and aluminium alloys diecasters (so far, in Europe and particularly in Portugal, there is no published benchmarking studies for the metalcasting industry);

2. to be focused on the so-called "critical factors" concerning the manufacturing perspective, innovation and improvement perspective and customer perspective; the selection of these 3 areas was inspired in the balanced scorecard methodology [8], and

3. to be based on a relational and hierarchical structure of indicators grouped in 3 categories:

- indicators that provide information about improvement performance practices (which are supposed to influence the performance results);

- indicators for assessing the performance results on critical factors (which, in turn, are supposed to explain, at least partially, the business results);

- indicators that evaluate the business results: profitability, productivity, growth and customers' satisfaction. 
The underlying rational is that consistent manufacturing performance is a basic condition for the survival and success of an industrial company: understanding in full detail and improving continuously the "manufacturing critical factors" seems to be a good and feasible strategy. However, implementing improvement strategies that only include, for instance, environment, safety, innovation and effectiveness (of the manufacturing processes), doesn't drive, necessarily, to positive results in the long term. Other functional capacities, such as employee motivation, customer focus and new product development, are also crucial for the success of the organisations and should be explored (see table 2).

The hierarchical structure referred in third principle can be illustrated using the following example: to evaluate the environmental performance one should develop indicators for measuring the resources consumption, the amount of solid waste and the amount of gaseous emissions. On the other hand, the sustainability of the environmental performance demands a proactive management of the resources and waste treatment. Accordingly, improvement practices have to be identified and evaluated. Following our example, (a) environmental management system implementation, (b) rate of resources consumption reduction, and (c) capacity of developing technical skills. Appropriate indicators should be defined for measuring the implementation of these practices. The selected indicators are summarised in table 2: (1) environmental management system, (2) moreclean technologies, (3) reuse of wastewater, (4) energy efficiency programme, (5) employees committed to environment, (6) environment training time.

The performance assessment model involves a broad and detailed structure of indicators that supply quantitative and qualitative information related to results and practices. For each area considered (manufacturing, customer focus, and business results) a number of performance indicators are used. Some indicators (usually involving numeric measurements) refer the results obtained on critical factors, while others (usually involving qualitative judgements) provide information about the performance on practices, which help in improving those results (see table 3).

The problem with the foundry-oriented process indicators is how to define them accurately (in order to avoid different interpretations at different organisation contexts). The following example illustrates how a promising indicator can originate wrong results. When using the "number of new products" to evaluate the new product development performance, it is common that all new references are taken in consideration. However, using this procedure, innovative products are not distinguished from those that result from simple modifications of the current products. A change on the size or on the coating shall be considered in the "number of new products"? This issue must be discussed in detail with the benchmarking partners. Unfortunately, this type of questions is usually disclosed only during the pilot benchmarking exercise.

Examples from the literature and suggestions from the benchmarking partners were used for guiding the development and definition of the indicators (step 7). It is frequent that companies force the inclusion of particular indicators (already being used internally) in the benchmarking indicators structure, because those internal indicators cause a great impact within the company when compared with the respective external values. This question shall be handled with care. In the one hand, those indicators are already tested and familiar. On the other hand, including them in the model tout court can lead to an excessive number of indicators.

Concluding, the development of performance indicators is a demanding activity. This is more evident when the assessment model is designed to attain specific benchmarking information required for different companies included in the benchmarking group.

\section{THE PILOT BENCHMARKING EXERCISE}

The purpose of the pilot benchmarking exercise carried out in the second part of this project was to test, correct, and validate the initial assessment model and indicators structure. A round of meetings hosted by APF was accomplished, putting together all of the companies involved. The central issue discussed in these meetings was the suitability of the questionnaire used to gather the benchmarking data (step 8).

The questionnaire is a 35-page document, divided in 2 parts. In the first one, the performance indicators are described. For each indicator, it is included a brief definition, the scope, the formula and the respective unit (days/employee, €/hour, $\%$, etc.). In the second part of the document, the data required for computing the indicators was defined in detail, in order to avoid that different contexts could generate data with different meanings. The qualitative indicators are measured using a scale with 3 or 4 response options. In order to minimise the subjectivity associated with the qualitative responses, a validation criteria was developed. 


\begin{tabular}{|c|c|c|c|c|c|}
\hline \multirow{3}{*}{$\begin{array}{l}\text { Critical } \\
\text { factors } \\
\text { Results } \\
\text { indicators }\end{array}$} & \multicolumn{5}{|c|}{ MANUFACTURING } \\
\hline & Environment & Safety & Process Innovation & Process Effectiveness & Employee Motivation \\
\hline & $\begin{array}{l}\text { - Water consumption } \\
\text { - Electricity } \\
\text { consumption } \\
\text { - Fuel gas } \\
\text { consumption } \\
\text { - Fuel oil } \\
\text { consumption } \\
\text { - Wastewater } \\
\text { - Slag generated } \\
\text { - Waste sand } \\
\text { - Metallic fines } \\
\text { - VOC emissions } \\
\end{array}$ & $\begin{array}{l}\text { - Labour accident } \\
\text { frequency rate } \\
\text { - Labour accident } \\
\text { severity rate }\end{array}$ & $\begin{array}{l}\text { - New manufacturing } \\
\text { process }\end{array}$ & $\begin{array}{l}\text { - Scrap percentage } \\
\text { - Rework percentage } \\
\text { - Availability } \\
\text { - Performance } \\
\text { - Quality } \\
\text { - Effectiveness index } \\
\text { - Breakdowns } \\
\text { - Downtime due to tool } \\
\text { setting }\end{array}$ & $\begin{array}{l}\text { - Staff manufacturing } \\
\text { turnover } \\
\text { - Adm. and support staff } \\
\text { turnover } \\
\text { - Manufacturing. early } \\
\text { leavers } \\
\text { - Adm. and support staff } \\
\text { early leavers } \\
\text { - Manufacturing } \\
\text { absenteeism } \\
\text { - Adm. and support staff } \\
\text { absenteeism }\end{array}$ \\
\hline $\begin{array}{l}\text { Practices } \\
\text { indicators }\end{array}$ & $\begin{array}{l}\text { - Environment } \\
\text { management } \\
\text { system } \\
\text { - More-clean } \\
\text { technologies } \\
\text { - Reuse of } \\
\text { wastewater } \\
\text { - Energy efficiency } \\
\text { programme } \\
\text { - Employees } \\
\text { committed to } \\
\text { environment } \\
\text { - Environment } \\
\text { training time }\end{array}$ & $\begin{array}{l}\text { - Safety } \\
\text { management } \\
\text { system } \\
\text { - Risk evaluation } \\
\text { - Risk control } \\
\text { - Employees } \\
\text { committed to } \\
\text { use protective } \\
\text { equipments } \\
\text { - Cost of personal } \\
\text { protective } \\
\text { equipments } \\
\text { - Employees } \\
\text { committed to } \\
\text { safety } \\
\text { - Safety training } \\
\text { time }\end{array}$ & $\begin{array}{l}\text { - Graduate } \\
\text { employees } \\
\text { - R\&D staffing } \\
\text { - Innovation training } \\
\text { time } \\
\text { - Implementing } \\
\text { employees ideas } \\
\text { - Information } \\
\text { sources } \\
\text { - R\&D investment } \\
\text { - Manufacturing } \\
\text { process innovation } \\
\text { investment } \\
\text { - R\&D projects } \\
\text { - Placements to } \\
\text { higher education } \\
\text { students } \\
\text { - Partnerships } \\
\text { - Manufacturing } \\
\text { management tools } \\
\text { - Quality tools }\end{array}$ & $\begin{array}{l}\text { - Team work for quality } \\
\text { improvement } \\
\text { - Scrap reduction } \\
\text { programme } \\
\text { - Effectiveness } \\
\text { improvement } \\
\text { programme } \\
\text { - Self-inspection } \\
\text { - Statistical process } \\
\text { control } \\
\text { - Certified suppliers } \\
\text { - Income deliveries on- } \\
\text { time } \\
\text { - Rejected supplies } \\
\text { - Suppliers assessment } \\
\text { - Staff manufacturing } \\
\text { training time } \\
\text { - Supervisors skill } \\
\text { - Staffing flexibility } \\
\text { - Labour productivity } \\
\text { - Informatisation } \\
\text { investment }\end{array}$ & $\begin{array}{l}\text { - Manufacturing staff } \\
\text { remuneration } \\
\text { - Adm. and support staff } \\
\text { remuneration } \\
\text { - Additional benefits } \\
\text { - Benefits coverage } \\
\text { - Employees satisfaction } \\
\text { - Number of supervisors } \\
\text { - Implementing } \\
\text { - Jobloyees ideas } \\
\text { - Face ubility } \\
\text { decrease } \\
\text { - Staff manufacturing } \\
\text { training time } \\
\text { - Adm. and support staff } \\
\text { training time } \\
\text { - New employees } \\
\text { familiarisation }\end{array}$ \\
\hline
\end{tabular}

\begin{tabular}{|c|c|c|c|}
\hline \multirow[b]{2}{*}{$\begin{array}{l}\text { Critical } \\
\text { factors }\end{array}$} & \multicolumn{3}{|c|}{ CUSTOMER FOCUS } \\
\hline & Meeting Customer Needs & New Customers Commitment & New product development \\
\hline $\begin{array}{l}\text { Results } \\
\text { indicators }\end{array}$ & $\begin{array}{l}\text { - Complaints } \\
\text { - Cancelled orders } \\
\text { - On-time delivers (value) } \\
\text { - On-time delivers (amount) } \\
\text { - Complaints handling lead time } \\
\text { - Order fulfilment lead time } \\
\text { - New products order fulfilment lead time }\end{array}$ & $\begin{array}{l}\text { - Sales from new customers (value) } \\
\text { - Number of new customers } \\
\text { (amount) } \\
\text { - Tenders submitted and not } \\
\text { accepted }\end{array}$ & $\begin{array}{l}\text { - Number of new products } \\
\text { - Sales from new products } \\
\text { - Lead time to launch new products }\end{array}$ \\
\hline $\begin{array}{l}\text { Practices } \\
\text { metrics }\end{array}$ & $\begin{array}{l}\text { - Satisfaction assessment } \\
\text { - Complaints reduction programme } \\
\text { - Scrap reduction programme } \\
\text { - Effectiveness improvement programme } \\
\text { - Manufacturing planning changes } \\
\text { - Face up to orders increase } \\
\text { - Communication } \\
\text { - Customer meetings }\end{array}$ & - Level of marketing investment & $\begin{array}{l}\text { - Graduate employees } \\
\text { - R\&D staffing } \\
\text { - Project teams } \\
\text { - Implementing employees ideas } \\
\text { - Information sources } \\
\text { - Level of marketing investment } \\
\text { - R\&D projects } \\
\text { Placements to higher education } \\
\text { students } \\
\text { - Partnerships } \\
\text { - Prototyping technologies } \\
\text { - Commercial methods } \\
\text { - Quality tools }\end{array}$ \\
\hline
\end{tabular}

BUSINESS RESULTS

Results metrics

\begin{tabular}{|l|l|l|l|}
\hline \multicolumn{4}{|c|}{ BuSINESS RESULTS } \\
\hline Profitability & \multicolumn{1}{|c|}{ Productivity } & \multicolumn{1}{c|}{ Growth } & Customer satisfaction \\
\hline - Return on capital employed & $\begin{array}{l}\text { - Sales per employee } \\
\text { - Value added per } \\
\text { - Return on net assets }\end{array}$ & $\begin{array}{l}\text { - \% sales growth } \\
\text { employee }\end{array}$ & $\begin{array}{l}\text { Customers loyalty } \\
\text { growth }\end{array}$ \\
\hline
\end{tabular}

Table 2- Proposed performance indicators structure 


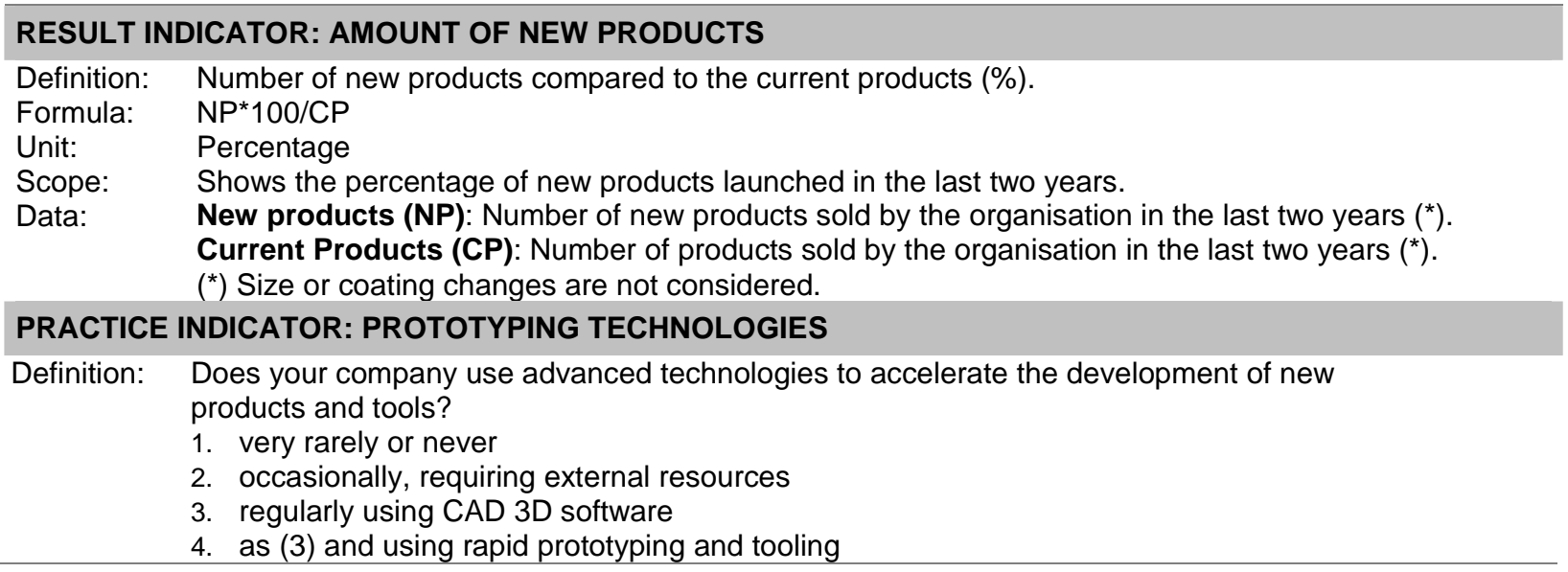

Table 3- Examples of quantitative and qualitative indicators for new product development evaluation

The data from the benchmarking questionnaires were segmented according to the foundries organisational and technological characteristics. The results were explored taking into account that they should be easily displayed and compared using graphics, tables, etc. The metrics were converted in a percentile scale and each organisation performance score was shown in a comparative bar chart (see figure 1). These charts are easy to analyse and allow the simultaneous representation of several indicators expressed in different units.

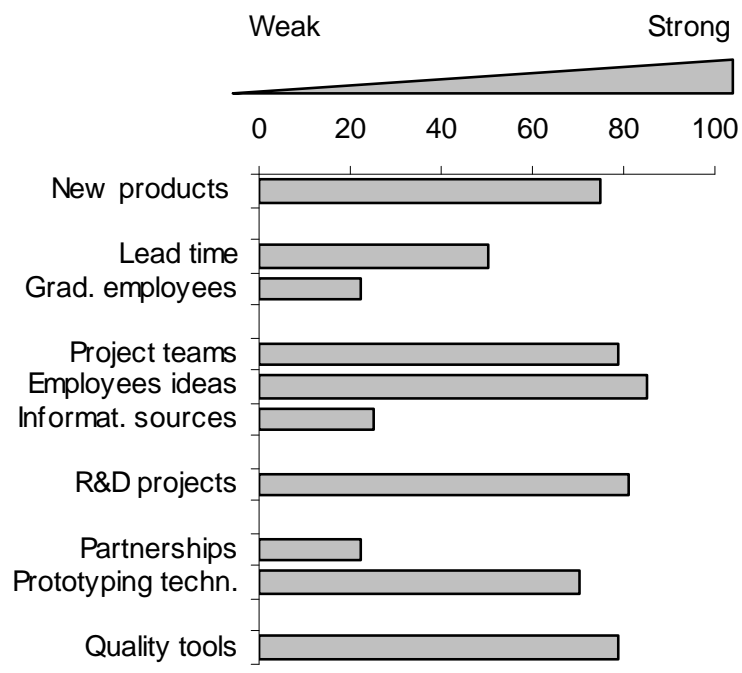

Figure 1-Bar chart comparing new product development performance against others

The pilot exercise revealed that the number of indicators envisaged initially was excessive. The following step consisted in the identification of those indicators not increasing relevant information. The initial performance indicator's structure was analysed using Analytic Hierarchy Process, relying again in the feedback of the participant companies. With this methodology, the relative importance of the critical factors and the relative priorities of the improvement strategies were determined in a pairwise basis.

The final benchmarking model for assessing the foundries' performance is now available at the APF. From now on, this institution can provide its members with a tool capable to promote the cooperation among companies and to enhance and enlarge significantly the information available about this sector.

In the future, it is intended that APF will explore its international contacts, aiming at exchanging benchmarking data and allowing mutual aid in the search for best practices. This activity will, certainly, help performance organisation's improvement that will contribute for the development of the metalcasting industry competitiveness

\section{References}

[1] Czuchry, A Yasin, M. Dorsh, J., A review of benchmarking literature: a proposed model for implemantation. Introduction Journal of Materials and Product Technology, 1995. 10 (1/2):p. 27-45.

[2] Camp, R. C., Benchmarking: the search for industry best practices that lead to superior performance, ASQC Quality Press. 1989.

[3] Bemowski, K., The Benchmarking Bandwagon. Quality Progress, 1991. Jan: p19-24.

[4] Spendolini, M. J., The Benchmarking Book, Amacon. 1992.

[5] Karlöf, B., Östblom, S., Benchmarking: a signpost to excellence in quality and productivity, John Wiley \& Sons. 1993.

[6] Codling, S., Benchmarking, Gower. 1998.

[7] Andersen, B., Jordan, P., Setting up a performance benchmarking network, Production Planning \& Control, 1998. 9 (1): 13-19.

[8] Kaplan, R. S., Norton, D. P., The balanced scorecard: translating strategy into action, Harvard Business School Press. 1996. 
